\title{
DIFFERENCES IN THE DETOXIFICATION METABOLISM BETWEEN TWO CLONAL LINEAGES OF THE APHID Myzus persicae (SULZER) (HEMIPTERA: APHIDIDAE) REARED ON TOBACCO (Nicotiana tabacum L.)
}

\author{
Marco A. Cabrera-Brandt ${ }^{1}$, Eduardo Fuentes-Contreras ${ }^{2}$, and Christian C. Figueroa ${ }^{*}$
}

\begin{abstract}
Myzus persicae (Sulzer) is a highly polyphagous aphid species, with a subspecies (M. persicae nicotianae) well adapted to tobacco (Nicotiana tabacum L.). We evaluated the effect of this host plant on the aphid performance and detoxification enzymes, in order to test the participation of xenobiotic metabolism on the ability of this aphid to overcome the tobacco chemical defences. Two genotypes, one corresponding to the only M. persicae nicotianae genotype reported in Chile on tobacco, and one genotype belonging to $M$. persicae sensu stricto were reared on tobacco and pepper (Capsicum annuum L.), respectively. M. persicae nicotianae showed a significantly higher intrinsic rate of increase $\left(\mathrm{r}_{\mathrm{m}}\right)$ on pepper than on tobacco, and M. persicae s.s. performed similarly, but with no reproduction at all on tobacco. In order to evaluate the effect of tobacco on detoxification enzymes, esterases, glutathione S-transferases (GST) and cytochrome P-450 monooxygenases (MO) were determined in both selected aphid genotypes after 12, 24, 36,48 and $72 \mathrm{~h}$ of rearing on tobacco and pepper. $M$. persicae nicotianae exhibited the higher total esterase activities when reared on tobacco than on pepper after $48 \mathrm{~h}$ of rearing, while the activities of GST and MO did not show any significant difference between host-plants and duration of treatment. For M. persicae s.s., no significant differences were observed among host-plants for the studied enzymes. These results suggest a participation of the esterases, on the ability of this $M$. persicae nicotianae to overcome the tobacco defences.
\end{abstract}

Key words: Myzus persicae nicotianae, Myzus persicae sensu stricto, detoxification enzymes, esterases, glutathione S-transferases, monooxygenases, intrinsic rate of increase.

\section{INTRODUCTION}

Aphids are ubiquitous herbivorous insects that frequently constitute agricultural pests. Among the most relevant aphid pests the peach-potato aphid, Myzus persicae (Sulzer), is a polyphagous insect able to utilise a wide range of weeds and crops belonging to more than 40 plant families (Blackman and Eastop, 2000). The tobacco aphid, Myzus persicae nicotianae, is a subspecies particularly well adapted to tobacco (Nicotiana tabacum L.), unlike M. persicae sensu stricto (Blackman, 1987; Eastop and Blackman, 2005; Blackman et al., 2007). Interclonal variation in the performance of $M$. persicae on different host-plants has been reported, but $M$. persicae s.s. frequently shows a poor performance on tobacco in relation with $M$. persicae nicotianae (Nikolakakis et al.,

${ }^{1}$ Universidad Austral de Chile, Facultad de Ciencias, Casilla 567, Valdivia, Chile. "Corresponding author (christianfigueroa@uach.cl). ${ }^{2}$ Universidad de Talca, Facultad de Ciencias Agrarias, Casilla 747, Talca, Chile.

Received: 1 January 2010.

Accepted: 5 July 2010.
2003; Olivares-Donoso et al., 2007). Interestingly, the tobacco aphid is also found on other host-plants, including peach Prunus persica, field crops of potato (Solanum tuberosum L.), pepper (Capsicum annuum L.) and cabbage (Brassica oleracea L.), as well as weeds (Semtner et al., 1998; Blackman et al., 2007; Margaritopoulos et al., 2007). Since wild and cultivated tobacco species show a number of anti-herbivore defences, the use of tobacco by $M$. persicae nicotianae should involve a fitness tradeoffs on this host-plant, which could be based on the antiherbivore defences produced by tobacco (Heidel and Baldwin, 2004), among which sugar esters (Neal et al., 1994; Xia and Johnson, 1997; Xia et al., 1997; Johnson et al., 2002; Puterka et al., 2003) and alkaloids (Thurston et al., 1966) produced by glandular trichomes are the major component of resistance against aphids. Those cuticular allelochemicals have been suggested as targets for tobacco breeding programs against $M$. persicae nicotianae on tobacco (Johnson et al., 2002; Goundoudaki et al., 2003), and could be related with the poor performance reported for $M$. persicae s.s. comparative with $M$. persicae nicotianae on this crop (Nikolakakis et al., 2003). 
In Chile, $M$. persicae nicotianae was not observed or reported until 1998 (Fuentes-Contreras et al., 2004). A previous work has shown the presence of a single predominant genotype on tobacco, which has been found to be widespread not only in Chile (Fuentes-Contreras et al., 2004), but also observed in high frequencies in USA, Brazil and Argentine populations (Zepeda-Paulo et al., 2010).

The success of $M$. persicae colonizing different hostplants has been related to the presence of aphid enzymatic mechanisms of detoxification, which are responsible for the metabolization of host-plant allelochemicals (Francis et al., 2005; 2006). Therefore, the performance of $M$. persicae nicotianae on tobacco should have a genetic/biochemical base, which could be related to the ability of this subspecies to colonize a well defended host plant (i.e. tobacco with glandular trichomes and cuticular sucrose esters).

We hypothesise that the $M$. persicae nicotianae enzymatic detoxification system plays a role in the ability of this aphid to overcome the tobacco defences. Hence, the aim of this work was to compare the activity of three well-known enzymes that detoxify xenobiotics in insects: esterases (EST), glutathione S-transferases (GST) and cytochrome P-450 monooxygenases (MO) in two aphid clonal lineages reared on contrasting hosts (chemically defended and non-defended plants). The study was conducted comparing the performance and detoxification activity in two highly common field genotypes of $M$. persicae: the Chilean single predominant genotype belonging to $M$. persicae nicotianae and one $M$. persicae s.s. genotype chosen based on its higher genetic distance shown with respect to $M$. persicae nicotianae genotype.

\section{MATERIALS AND METHODS}

\section{Aphids and plants}

A total of 59 individual aphids were sampled in Central Chile. Thirty six individuals were collected from $N$. tabacum, 12 individuals were collected from weeds including Brassica rapa L. (Brassicaceae), Datura stramonium L. (Solanaceae), Polygonum persicaria L. (Polygonaceae), and Chenopodium album L. (Chenopodiaceae), and eleven individuals were collected from crops including Beta vulgaris var. saccharifera L. (Chenopodiaceae), Prunus persica (L.) Batsch. (Rosaceae), and Prunus domestica L. (Rosaceae).

Once in the laboratory, M. persicae nicotianae aphids collected from tobacco were individually reared on $N$. tabacum var. burley var. BY64 (Profigen do Brazil, Brazil), while $M$. persicae s.s. aphids collected from weeds and non-tobacco crops were individually reared on pepper (C. annuиm var. grossum) cv. Resistant (PetoSeed, Chile). Those host-plants were chosen because aphids exhibit their optimal growth (Olivares-Donoso et al., 2007).

Aphids and plants were kept in climate rooms under controlled conditions $\left(20 \pm 0.1{ }^{\circ} \mathrm{C}, 16: 8\right.$ photoperiod $)$, which ensure the parthenogenetic reproduction of aphids. Hence, each individual produced a genetically identical colony or clonal lineage. Samples from each clonal lineage were used to confirm species following taxonomic keys. Before experiments, aphids were left to reproduce on their optimal host-plants for at least three generations, to prevent any maternal effect or grand-maternal effects, a consequence of the telescopic reproduction in aphids.

\section{Microsatellite genotyping}

Once clonal lineages were established, they were genotyped using 10 microsatellite loci previously described (Sloane et al., 2001; Wilson et al., 2002). The DNA isolation was carried out following the "salting-out" method (Sunnucks and Hales, 1996) using one individual from each of the 59 laboratory clonal lineages. Microsatellite loci were amplified by the polymerase chain reaction (PCR) and the products separated through an electrophoresis in polyacrylamide gels stained with silver nitrate. The size of each fragment (microsatellite alleles) was determined by size comparison with the sequence of the pGEM - $3 Z F(+)$ vector (Promega, Madison, Wisconsin, USA) loaded in the same gel.

\section{Evaluation of aphid intrinsic rate of increase}

Synchronized second instar aphids from the selected M. persicae nicotianae and M. persicae s.s. genotypes were obtained from clip-cages placed on leaves of their respective host-plants (tobacco or pepper). Nymphs were gently removed with a paint brush and carefully placed on leaves of either tobacco or pepper. All evaluations were performed on plants maintained in a growth chamber with controlled temperature and photoperiod $\left(20 \pm 0.1{ }^{\circ} \mathrm{C}, 16: 8\right.$ h). The pre-reproductive duration (T) and fecundity (M) during a $2 \mathrm{~T}$ period were daily recorded. This information was used to calculate the intrinsic rate of increase $\left(\mathrm{r}_{\mathrm{m}}\right)$ of the two M. persicae genotypes on both tobacco and pepper, according to the method described by Wyatt and White (1977). Each experiment was replicated $(n=12)$ and differences analyzed with Kruskal-Wallis test (Sokal and Rohlf, 1995).

\section{Host-plant transfer experimental design}

Synchronized wingless adult aphids from the chosen $M$. persicae nicotianae and M. persicae s.s. genotypes (clonal lineages) were reared on tobacco and pepper, respectively, and then transferred to: (i) their same optimal host-plant (control), and to (ii) a different plant (treatments from tobacco to pepper and from pepper to tobacco). All 
evaluations were performed using plants maintained in a growth chamber with controlled temperature and photoperiod $\left(20 \pm 0.1{ }^{\circ} \mathrm{C}, 16: 8 \mathrm{~h}\right)$. Twelve, 24, 36, 48 and $72 \mathrm{~h}$ after the aphids were transferred to a new host-plant; they were immediately used for enzymatic determinations. The enzymatic determinations for each time period mentioned above were conducted in three blocks of 10 replicates each (30 each time).

\section{Detoxification enzymes}

Total EST activity was determined by photometry (Devonshire et al., 1992), while GST and MO activity were determined by fluorometry (De Sousa et al., 1995; Nauen and Stumpf, 2002). Total proteins were quantified following the Bradford (1976) method using bovine serum albumin as standard.

Esterases. The total activity of EST was determined using $\alpha$-naphtyl-acetate ( $\alpha$-NA) as substrate (Devonshire et al., 1992). One single aphid from each treatment was homogenized in $100 \mu \mathrm{L}$ buffer PBS/TWEEN 20. Then, 25 $\mu \mathrm{L}$ of each homogenized were transferred to a transparent 96-wells microplate, adding $25 \mu \mathrm{L}$ of buffer PBS/TRITON $\mathrm{X}-100$. Next, $150 \mu \mathrm{L}$ of $\alpha$-NA (in buffer PBS/TRITON $\mathrm{X}$-100) were added and incubated for $5 \mathrm{~min}$ at room temperature. The reaction was stopped with $25 \mu \mathrm{L}$ of dying solution (Fast blue RR salt) and left in darkness for $20 \mathrm{~min}$ at room temperature. The absorbance was read at $620 \mathrm{~nm}$ using a Victor 3 Wallac microplate reader (Perkin Elmer Life and Analytical Sciences, USA), and the results were expressed as nmoles $\alpha$-naphtol $\mathrm{min}^{-1} \mathrm{mg}^{-1}$ protein.

Glutathione S-transferase. The activity of GST was determined using monochlorobimane as substrate (Nauen and Stumpf, 2002). Five aphids of the same clonal lineage from each treatment were homogenized in $300 \mu \mathrm{L}$ of buffer PBS $1 \mathrm{X}$ and centrifuged at 10000 RPM during 5 min at $4{ }^{\circ} \mathrm{C}$. Then, $30 \mu \mathrm{L}$ of the supernatant (enzymatic extract) were transferred to a black 96-wells microplate, adding $30 \mu \mathrm{L}$ of PBS $1 \mathrm{X}$ and $150 \mu \mathrm{L}$ of substrate (reduced Glutathione in HEPES buffer). Next, $20 \mu \mathrm{L}$ of monochlorobimane (in HEPES buffer) were added to each well, incubating at room temperature for $20 \mathrm{~min}$. The fluorescence was measured at $390 \mathrm{~nm}$ for excitation and $465 \mathrm{~nm}$ for emission using a microplate reader. Because the product bimane-glutathione adduct $(\mathrm{GS}-\mathrm{mCB})$ is not commercially available, the results were expressed as fluorescence units of GS-mCB per insect (Nauen and Stumpf, 2002).

Cytochrome P-450 monooxygenases. The activity of MO was determined using the 7-ethoxycoumarine$O$-deethylase activity (De Sousa et al., 1995). Three aphids of the same genotype from each condition were gently crushed in $150 \mu \mathrm{L}$ of buffer HEPES in a black 96-wells microplate, adding $100 \mu \mathrm{L}$ of substrate $(0.4 \mathrm{mM}$ ethoxycoumarin in $50 \mathrm{mM}$ buffer phosphate, $\mathrm{pH}$ 7.2). For the controls, the same volume of buffer glycine/ethanol $(50 \% \mathrm{v} / \mathrm{v})$ was added to avoid the reaction. Then, the reaction was incubated for $4 \mathrm{~h}$ at $37{ }^{\circ} \mathrm{C}$ and stopped by the addition of $100 \mu \mathrm{L}$ of buffer glycine/ethanol $(50 \%$ $\mathrm{v} / \mathrm{v})$. Fluorescence was read at $390 \mathrm{~nm}$ for excitation and $460 \mathrm{~nm}$ for emission, using a microplate reader. The results were expressed in amount of fluorescent product 7-hidroxycoumarin, ng $\min ^{-1}$ (De Sousa et al., 1995).

\section{Data analysis}

Enzymatic activities of EST, GST and MO were analyzed separately for each aphid belonging to the chosen $M$. persicae nicotianae and $M$. persicae s.s. clonal lineages. Independent variables were: i) transfer between hostplant species (tobacco to tobacco as control and tobacco to pepper for M. persicae nicotianae) (pepper to pepper as control and pepper to tobacco for M. persicae s.s.), and ii) hours since host-plant species transfer (12, 24, 36, 48 and $72 \mathrm{~h}$ ), using an ANOVA for repeated measures on time (Sokal and Rohlf, 1995).

\section{RESULTS}

The genotyping showed that most microsatellite alleles were in the size range previously described for $M$. persicae (Terradot et al., 1999; Sloane et al., 2001; Wilson et al., 2002; Fuentes-Contreras et al., 2004; Blackman et al., 2007; Margaritopoulos et al., 2007; Zepeda-Paulo et al., 2010). After combining the genotypes from all the amplified loci, 15 multilocus genotypes were identified among the 59 clonal lineages. Fourteen genotypes were found on weeds and non-tobacco crops, while a single genotype was detected on tobacco, as previously reported. Based on the proportion of shared alleles, the most genetically distant $M$. persicae s.s. genotype in relation to the single $M$. persicae nicotianae genotype was selected for further comparisons.

Aphid intrinsic rate of increase $\left(\mathrm{r}_{\mathrm{m}}\right)$ was significantly lower for M. persicae s.s. reared on tobacco, where no reproduction was observed in $\mathrm{T}$ and $2 \mathrm{~T}$. Also, both $M$. persicae nicotianae $\left(\mathrm{r}_{\mathrm{m}}=0.259 \pm 0.011\right)$ and $M$. persicae s.s. $\left(\mathrm{r}_{\mathrm{m}}=0.282 \pm 0.005\right)$ reared on pepper showed a significantly higher $\mathrm{r}_{\mathrm{m}}$ than $M$. persicae nicotianae on tobacco $\left(\mathrm{r}_{\mathrm{m}}=0.181 \pm 0.018\right)\left(\mathrm{H}_{2,34}=14.95, P<0.001\right)$ (Table 1).

The enzymatic activity of EST showed no significant differences between host-plant species for both $M$. persicae nicotianae $\left(\mathrm{F}_{1,58}=3.4, P=0.07\right)$ and $M$. persicae s.s. $\left(\mathrm{F}_{1,58}=0.7, P=0.39\right)$. However, there were 
Table 1. Intrinsic rate of increase $\left(r_{m}\right)$ of Myzus persicae s.s. and $M$. persicae nicotianae reared on tobacco and pepper $(n=12)$.

\begin{tabular}{lcc}
\hline & \multicolumn{2}{c}{$\mathbf{r}_{\mathrm{m}}$} \\
\cline { 2 - 3 } Aphids & On pepper & On tobacco \\
\hline M. persicae nicotianae & $0.259 \pm 0.011$ & $0.181 \pm 0.018$ \\
$M$. persicae s.s. & $0.282 \pm 0.005$ & $\mathrm{NR}$ \\
\hline
\end{tabular}

NR: no reproduction was observed.

Both aphid clonal lineages on pepper showed a significantly higher $\mathrm{r}_{\mathrm{m}}$ than M. persicae nicotianae on tobacco $\left(\mathrm{H}_{2,34}=14.95, \mathrm{P}<0.001\right)$.
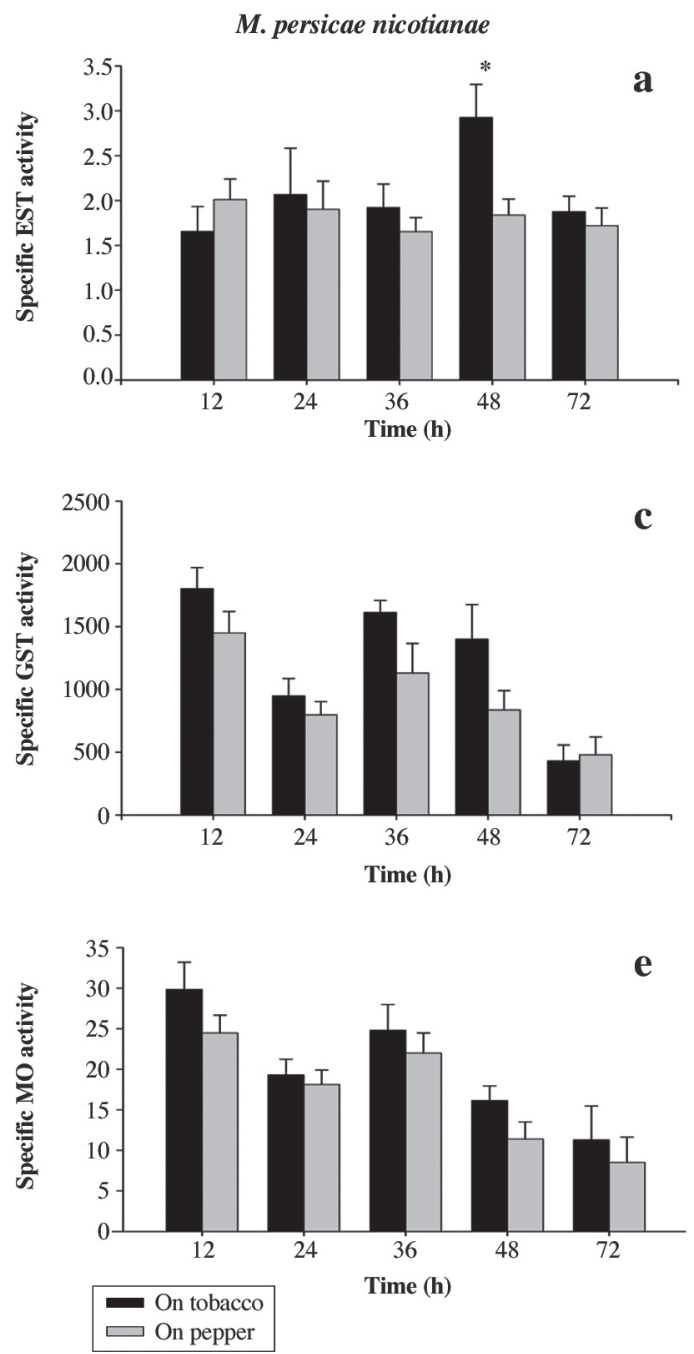

significant differences between hours since host-plant transfer for both $M$. persicae nicotianae $\left(\mathrm{F}_{4,232}=4.6, P=\right.$ $0.001)$ and $M$. persicae s.s. $\left(\mathrm{F}_{4,232}=2.6, P=0.04\right)$ aphids. Similarly, there was a significant interaction between hostplant transfer and hours since host-plant transfer effects for $M$. persicae nicotianae $\left(\mathrm{F}_{4,232}=5.2, P<0.001\right)$, but not for M. persicae s.s. $\left(\mathrm{F}_{4,232}=2.0, P=0.09\right)$. Multiple comparisons revealed that such statistical interaction was based on a significant increase of EST activity of $M$. persicae nicotianae genotype at $48 \mathrm{~h}$ since transfer from tobacco to tobacco in relation to all remaining hours (LSD test, $P<0.05$ ), which was not observed when transferred from tobacco to pepper at any hours since host-plant transfer (Figure 1).
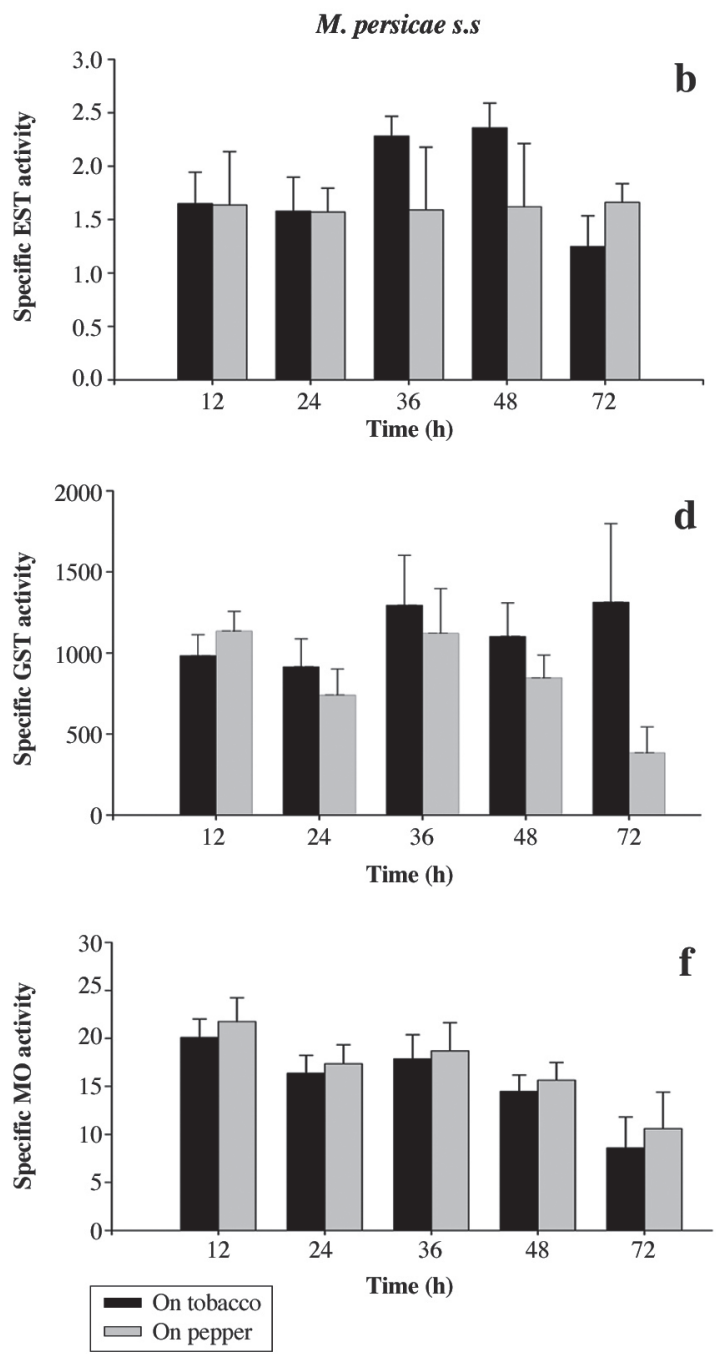

a and b: Specific esterases (EST) activities (nmoles $\alpha$-naphtol $\mathrm{min}^{-1} \mathrm{mg}^{-1}$ protein $)(\mathrm{n}=30$ enzymatic determinations for each time); $\mathrm{c}$ and $\mathrm{d}$ : specific glutathione $\mathrm{S}$ transferase (GST) activities (fluorescence units of GS-mCB per insect) ( $\mathrm{n}=30$ enzymatic determinations for each time); e and f: specific cytochrome P-450 monooxygenases (MO) activities (ng of fluorescent product 7-hidroxycoumarin min $\left.^{-1}\right)(n=30$ enzymatic determinations each time).

*Significant differences $(\mathrm{F} 4,232=5.2, \mathrm{P}<0.001)$ (Error bars: standard error).

Figure 1. Enzyme activities of Myzus persicae nicotianae and M. persicae s.s. (black on tobacco; grey on pepper). 
The enzymatic activity of GST showed no significant differences between host-plant species for both $M$. persicae nicotianae $\left(\mathrm{F}_{1,58}=2.7, P=0.11\right)$ and $M$. persicae s.s. $\left(\mathrm{F}_{1,58}=1.02, P=0.32\right)$. However, there were significant differences between hours since host-plant transfer for both $M$. persicae nicotianae $\left(\mathrm{F}_{4,232}=24.1\right.$, $P<0.001)$ and $M$. persicae s.s. $\left(\mathrm{F}_{4,232}=20.4, P<0.001\right)$ aphid genotypes. No significant interactions between hostplant transfer and hours since host-plant transfer effects for both $M$. persicae nicotianae $\left(\mathrm{F}_{4,232}=1.3, P=0.28\right)$ and $M$. persicae s.s. genotype $\left(\mathrm{F}_{4,232}=0.96, P=0.43\right)$ were found. Multiple comparisons showed a significant decrease of GST activity at $72 \mathrm{~h}$ since host-plant transfer in relation to all remaining hours (LSD test, $P<0.05$ ) for both Myzus subspecies and host-plant transfer treatments (Figure 1).

Cytochrome P-450 monooxygenases activity showed no significant differences between host-plant species for both $M$. persicae nicotianae $\left(\mathrm{F}_{1,58}=2.0, P=0.16\right)$ and $M$. persicae s.s. $\left(\mathrm{F}_{1,58}=0.18, P=0.67\right)$. However, there were significant differences between hours since host-plant transfer for both $M$. persicae nicotianae $\left(\mathrm{F}_{4,232}=74.0\right.$, $P<0.001)$ and $M$. persicae s.s. $\left(\mathrm{F}_{4,232}=41.6, P<0.001\right)$ aphid. No significant interactions between host-plant and time treatment for both $M$. persicae nicotianae $\left(\mathrm{F}_{4,232}=\right.$ $1.9, P=0.11)$ and M.persicae s.s. $\left(\mathrm{F}_{4,232}=0.34, P=0.85\right)$ were found. Multiple comparisons showed a significant decrease of MO activity at $72 \mathrm{~h}$ since host-plant transfer (Least Significant Difference test, $P<0.05$ ) for both subspecies and host-plant transfer treatments (Figure 1).

\section{DISCUSSION}

Evidences of the involvement of detoxification enzymes in the ability of $M$. persicae s.s to face secondary metabolites (such as glucosinolates and isothiocyanates) from Brassicaceae plants have been reported (Francis $e t$ $a l ., 2005 ; 2006)$. Those studies have shown that aphids fed for 2-wk on Brassica plants have evidenced an induction of GST activities, which has been discussed in terms of insect adaptation to the presence of plant allelochemicals (Francis et al., 2005; 2006). Furthermore, GST and other detoxifying enzymes such as MO have been shown to aid cereal aphids to use Poaceae host-plants with high levels of hydroxamic acids, a family of plant secondary metabolites that show anti-herbivore and anti-feeding activities (Leszczynski et al., 1994; Figueroa et al., 1999, 2004; Loayza-Muro et al., 2000; Mukanganyama et al., 2003; Niemeyer, 2009). For EST, higher enzymatic activities were observed in Rhopalosiphum padi reared on resistant wheat varieties compared to susceptible ones (Cai et al., 2004), while increased levels of EST activities were observed in Sitobion avenae as a response to dietary concentrations of the indole alkaloid gramine, suggesting that EST are involved in detoxification of plant chemical defences (Cai et al., 2009).

In our study we did not found any significant differences in GST or MO activity attributable to the change of host-plant, but a significant increase in the total activity of EST was found after $48 \mathrm{~h}$ of transferring $M$. persicae nicotianae aphids from tobacco to tobacco. It is important to note here, that our results were obtained after a 3-d rearing period on tobacco and pepper, while the involvement of GST in response to plant allelochemicals was reported after 2-wk of rearing on Brassica plant and 1-wk of rearing on artificial diets (Francis et al., 2005; 2006).

This higher total activity of EST observed after $48 \mathrm{~h}$ on tobacco, could be related with the settlement phase of the aphids on the tobacco leaf surface. After transferring aphids, they get in contact with tobacco trichomes, which release sugar esters known to produce deleterious effects on M. persicae nicotianae performance (Xia and Johnson, 1997; Xia et al., 1997; Johnson et al., 2002; Puterka et al., 2003; Goundoudaki et al., 2003). At present, there are no studies about the mechanisms of toxicity of sucrose and glucose esters from tobacco trichomes on insects, although it has been proposed that they could disrupt the integrity of cellular membranes, and uncouple oxidative phosphorylation, similar to the action of insecticidal soaps (Neal et al., 1994; Xia et al., 1997; Puterka et al., 2003). Similarly, it is unclear how these leaf surface cuticular components, bound to water soluble sugars could cross the aphid cuticle and interact with enzymes inside the aphid. However, it is possible that microbial activity in the phyloplane could naturally break-down the sugars after several hours, releasing fatty acids with lipophilic acyl chains and free hydroxyls that could affect insect cuticle (Puterka et al., 2003). The increase of total EST activity after $48 \mathrm{~h}$ on tobacco observed in our experiments could be related with a time lag necessary for the sugar esters to be modified and induce the increase of enzyme activity inside the aphid body.

Detoxification of plant allelochemicals in insects is frequently related with insecticide detoxification, often sharing the same enzymatic mechanisms (Li et al., 2007). One of the main mechanisms of insecticide resistance in M. persicae is the amplification of one of two closely related genes, which express carboxylesterase enzymes (E4 and FE4). These carboxylesterases hydrolyse or sequester insecticide esters (Devonshire et al., 1992; Field and Blackman, 2003). A chromosome translocation is associated with the duplication of copies of the $E 4$ gene in a single site, while the amplification of copies of the FE4 gene is unrelated with chromosomal translocations and can be found at several loci throughout the genome 
(Field and Blackman, 2003). M. persicae s.s. and M. persicae nicotianae show the same mechanism of insecticide resistance based on E4 and FE4 activity (Field et al., 1994). We have found that M. persicae nicotianae could be able to increase the total EST activity following its transfer to tobacco plants. However, since epigenetic control of E4 and FE4 expression, based on chromosomal translocation or gene methylation processes, involve heritable and more permanent changes in the aphid genome, it is unlikely that they could be involved in the transient increase of total EST activity that we observed within a scale of hours. In addition, the M. persicae nicotianae genotype used in this study is the same previously reported to be predominant in Chile (Fuentes-Contreras et al., 2004), which was characterized as a chromosome translocated R1 genotype with a rather low to mid level of total EST activity. Similarly, the $M$. persicae s.s. genotype selected for this study showed total EST activity in a similar range with the $M$. persicae nicotianae genotype. Then, other carboxylesterases could be involved in the response observed in our study. Indeed, a group of five carboxylesterase genes in $M$. persicae that show a high sequence homology to carboxylesterase lipase superfamily in Acyrthosiphon pisum, have been reported to participate in xenobiotic detoxification (Zhu et al., 1999; Claudianos et al., 2006; Ramsey et al., 2010).

The host-plant use in $M$. persicae has been shown to involve significant performance trade-offs. It has been found M. persicae nicotianae showed better performance on tobacco than did M. persicae s.s. and there was a (less marked) better performance of M. persicae s.s. in relation to M. persicae nicotianae on pepper (Nikolakakis et al., 2003; Olivares-Donoso et al., 2007). The genotype of $M$. persicae s.s. used in our study was not able to use tobacco as a suitable host-plant, and thus agrees with the fitness trade-off already described. Similarly, common (asexual) and sexual genotypes from a non-tobacco growing areas of Greece and from southern Italy do not have the ability to use tobacco as a suitable host-plant (Nikolakakis et al., 2003; Margaritopoulos et al., 2003; 2005; Blackman et al., 2007). On the other hand, the genotype of $M$. persicae nicotianae used in our study exhibited a higher performance on pepper than on tobacco, which reinforces the notion that $M$. persicae nicotianae can use other plant species as suitable hosts like tobacco (Semtner et al., 1998; Nikolakakis et al., 2003; Blackman et al., 2007).

\section{CONCLUSIONS}

The findings here reported suggest the presence of fitness costs associated with the use of tobacco as a host-plant, and the involvement of esterases as an aphid response, which was observed following the host plant transfer to tobacco (a defended plant). Detoxification enzymes seem to be one of the main traits allowing $M$. persicae nicotianae to overcome tobacco defences, which is a point to consider during host specialization to tobacco.

\section{ACKNOWLEDGEMENTS}

This work is part of the activities of the Centre for Research on Plant-Insect Interactions (iCROP), and was funded by FONDECYT 3020051 and 1050644 grants. Partial support was also obtained from CONICYT-PBCT Anillos ACT-38 grant. We also thank Luis Castañeda for his help with statistical analysis and criticisms.

\section{RESUMEN}

Diferencias en el metabolismo de detoxificación entre dos linajes clonales del áfido Myzus persicae (Sulzer) (Hemiptera: Aphididae) criados sobre tabaco (Nicotiana tabacum L.). Myzus persicae (Sulzer) es un áfido polífago que incluye a Myzus persicae nicotianae, una subespecie altamente adaptada sobre tabaco (Nicotiana tabacum L.). Evaluamos el efecto del tabaco sobre el desempeño biológico y sobre determinadas enzimas de detoxificación en áfidos, para estudiar su participación en la capacidad de M. persicae nicotianae de superar las defensas químicas del tabaco. Dos genotipos de M. persicae, uno correspondiente al único genotipo perteneciente a $M$. persicae nicotianae reportado en Chile sobre tabaco y el otro perteneciente a M. persicae sensu stricto, fueron criados sobre tabaco y pimentón (Capsicum annuиm L.), respectivamente. M. persicae nicotianae mostró una tasa intrínseca de crecimiento $\left(\mathrm{r}_{\mathrm{m}}\right)$ significativamente mayor sobre pimentón que sobre tabaco, mientras que $M$. persicae s.s. no se reprodujo sobre tabaco. Para evaluar los efectos del tabaco sobre el metabolismo de detoxificación, se determinó la actividad de las enzimas esterasas, glutation S-transferasas (GST) y citocromo p450 monooxigenasas (MO), transcurridas $12,24,36,48$ y $72 \mathrm{~h}$ desde que ambos genotipos fueran transferidos desde su planta hospedera óptima a una nueva planta de tabaco y pimentón. En M. persicae nicotianae, se observaron diferencias significativas en las esterasas cuando se alimenta sobre tabaco, transcurridas $48 \mathrm{~h}$ desde el inicio del experimento. Para M. persicae s.s. no se observaron diferencias significativas en las actividades de las enzimas estudiadas durante el experimento. Estos resultados sugieren la participación de las esterasas en la capacidad de $M$. persicae nicotianae para enfrentar las defensas químicas del tabaco.

Palabras clave: Myzus persicae nicotianae, Myzus persicae s.s., enzimas de detoxificación, esterasas, glutatión $\mathrm{S}$ transferasa, monooxigenasas, tasa intrínseca de crecimiento. 


\section{LITERATURE CITED}

Blackman, R.L. 1987. Morphological discrimination of a tobacco-feeding form from Myzus persicae (Sulzer) (Hemiptera: Aphididae), and a key to New World Myzus (Nectarosiphon) species. Bulletin of Entomological Research 77:713-730.

Blackman, R.L., and V.F. Eastop. 2000. Aphids on the World's crops: An identification guide. $2^{\text {nd }}$ ed. 466 p. Wiley, Chichester, UK.

Blackman, R.L., G. Malarky, J.T. Margaritopoulos, and J.A. Tsitsipis. 2007. Distribution of common genotypes of Myzus persicae (Hemiptera: Aphididae) in Greece, in relation to life cycle and host plant. Bulletin of Entomological Research 97:253-263.

Bradford, M.M. 1976. A rapid and sensitive method for the quantitation of microgram quantities of protein utilizing the principle of protein-dye binding. Analytical Biochemistry 72:248-254.

Cai, Q.N., Y. Han, Y.Z. Cao, Y. Hu, X. Zhao, and J.L. Bi. 2009. Detoxification of gramine by the cereal aphid Sitobion avenae. Journal of Chemical Ecology 35:320-325

Cai, Q.N., Q.W. Zhang, and M. Cheo. 2004. Contribution of indole alkaloids to Sitobion avenae (F.) resistance in wheat. Journal of Applied Entomology 128:517521.

Claudianos, C., H. Ranson, R.M. Johnson, S. Biswas, M.A. Schuler, and M.R. Berenbaum. 2006. A deficit of detoxification enzymes: pesticide sensitivity and environmental response in the honeybee. Insect Molecular Biology 15:615-636.

De Sousa, G., A. Cuany, A. Brun, M. Amichot, R. Rhamani, and J.B. Bergé. 1995. A microfluorimetric method for measuring ethoxycoumarin- $O$-deethylase activity on individual Drosophila melanogaster abdomens: interest for screening resistance in insect populations. Analytical Biochemistry 229:86-91.

Devonshire, A.L., G.J. Devine, and G.D. Moores. 1992. Comparison of microplate esterase assays and immunoassay for identifying insecticide resistant variants of Myzus persicae (Homoptera: Aphididae). Bulletin of Entomological Research 82:459-463.

Eastop, V.F., and R.L. Blackman. 2005. Some new synonyms in Aphididae (Hemiptera: Sternorrhyncha). Zootaxa 1089:1-36.

Field, L.M., and R.L. Blackman. 2003. Insecticide resistance in the aphid Myzus persicae (Sulzer): Chromosome location and epigenetic effects on esterase gene expression in clonal lineages. Biological Journal of the Linnean Society 79:107-113.
Field, L.M., N. Javed, M.F. Stribley, and A.L. Devonshire. 1994. The peach-potato aphid Myzus persicae and the tobacco aphid Myzus nicotianae have the same esterase-based mechanisms of insecticide resistance. Insect Molecular Biology 3:143-148.

Figueroa, C.C., C. Koenig, C. Araya, M.J. Santos, and H.M. Niemeyer. 1999. Effect of DIMBOA, a hydroxamic acid from cereals, on peroxisomal and mitochondrial enzymes from aphids: Evidence for the presence of peroxisomes in aphids. Journal of Chemical Ecology 25:2465-2475.

Figueroa, C.C., J.-C. Simon, J.-F. Le Gallic, N. PrunierLeterme, L.M. Briones, C.-A. Dedryver, and H.M. Niemeyer. 2004. Effect of host defense chemicals on clonal distribution and performance of different genotypes of the cereal aphid Sitobion avenae (Hemiptera: Aphididae). Journal of Chemical Ecology 30:2515-2525.

Francis, F., P. Gerkens, N. Harmel, G. Mazzucchelli, E. De Pauw, and E. Haubruge. 2006. Proteomics in Myzus persicae: effect of aphid host plant switch. Insect Biochemistry and Molecular Biology 36:219227.

Francis, F., N. Vanhaelen, and E. Haubruge. 2005. Glutathione S-transferases in the adaptation to plant secondary metabolites in the Myzus persicae aphid. Archives of Insect Biochemistry and Physiology 58:166-174.

Fuentes-Contreras, E., C.C. Figueroa, M. Reyes, L.M. Briones, and H.N. Niemeyer. 2004. Genetic diversity and insecticide resistance of Myzus persicae (Hemiptera: Aphididae) populations from tobacco in Chile: evidence for the existence of a single predominant clone. Bulletin of Entomological Research 94:11-18.

Goundoudaki, S., J.A. Tsitsipis, J.T. Margaritopoulos, K.D. Zarpas, and S. Divanidis. 2003. Performance of the tobacco aphid Myzus persicae (Hemiptera: Aphididae) on Oriental and Virginia tobacco varieties. Agricultural and Forest Entomology 5:285291.

Heidel, A.J., and I.T. Baldwin. 2004. Microarray analysis of salicylic acid- and jasmonic acid-signalling in responses of Nicotiana attenuata to attack by insects from multiple feeding guilds. Plant Cell and Environment 27:1362-1373.

Johnson, A.W., V.A. Sisson, M.E. Snook, B.A. Fortnum, and D.M. Jackson. 2002. Aphid resistance and leaf surface chemistry of sugar ester producing tobaccos. Journal of Entomological Science 37:154-165. 
Leszczynski, B., H. Matok, and A.F.G. Dixon. 1994. Detoxification of cereal plant allelochemicals by aphids: Activity and molecular weights of glutathione $S$-transferase in three species of cereal aphids. Journal of Chemical Ecology 20:387-394.

Li, X., M.A. Schuler, and M.R. Berenbaum. 2007. Molecular mechanisms of metabolic resistance to synthetic and natural xenobiotics. Annual Review of Entomology 52:231-53.

Loayza-Muro, R., C.C. Figueroa, and H.M. Niemeyer. 2000. Effect of two wheat cultivars differing in hydroxamic acid concentration on detoxifying and oxidative metabolism in the aphid Sitobion avenae. Journal of Chemical Ecology 26:2725-2731.

Margaritopoulos, J.T., R.L. Blackman, J.A. Tsitsipis, and L. Sannino. 2003. Co-existence of different host-adapted forms of the Myzus persicae group (Hemiptera: Aphididae) in southern Italy. Bulletin of Entomological Research 93:131-135.

Margaritopoulos, J.T., G. Malarky, J.A. Tsitsipis, and R.L. Blackman. 2007. Microsatellite DNA and behavioural studies provide evidence of host-mediated speciation in Myzus persicae (Hemiptera: Aphididae). Biological Journal of the Linnean Society 91:687-902.

Margaritopoulos, J.T., C. Tsourapas, M. Tzortzi, O.M. Kanavaki, and J.A. Tsitsipis. 2005. Host selection by winged colonisers within the Myzus persicae group: a contribution towards understanding host specialisation. Ecological Entomology 30:406-418.

Mukanganyama, S., C.C. Figueroa, J.A. Hasler, and H.M. Niemeyer. 2003. Effects of DIMBOA on detoxification enzymes of the aphid Rhopalosiphum padi (Homoptera: Aphididae). Journal of Insect Physiology 49:223-229.

Nauen, R., and N. Stumpf. 2002. Fluorometric microplate assay to measure glutathione $S$-transferase activity in insects and mites using monochlorobimane. Analytical Biochemistry 303:194-198.

Neal, J.W. Jr., J.G. Buta, G.W. Pittarelli, W.R. Lusbi, and J.A. Bentz. 1994. Novel sucrose esters from Nicotiana gossei: Effective biorationals against selected horticultural pests. Journal of Economic Entomology 87:1600-1607.

Niemeyer, H.M. 2009. Hydroxamic acids derived from 2-hydroxy-2H-1,4-benzoazin-3(4H)-ones: key defense chemicals of cereals. Journal of Agriculture and Food Chemistry 57:1677-1696.

Nikolakakis, N.N., J.T. Margaritopoulos, and J.A. Tsitsipis. 2003. Performance of Myzus persicae (Hemiptera: Aphididae) clones on different host-plants and their host preference. Bulletin of Entomological Research 93:235-242.
Olivares-Donoso, R., A.J. Troncoso, D.H. Tapia, D. Aguilera-Olivares, and H.M. Niemeyer. 2007. Contrasting performances of generalist and specialist Myzus persicae (Hemiptera: Aphididae) reveal differential prevalence of maternal effects after host transfer. Bulletin of Entomological Research 97:61-67.

Puterka, G.J., W. Farone, T. Palmer, and A. Barrington. 2003. Structure-function relationships affecting the insecticidal and miticidal activity of sugar esters. Journal of Economic Entomology 96:636-644.

Ramsey, J.S., D.S. Rider, T. Walsh, M. de Vos, K. Gordon, L. Ponnala, et al. 2010. Comparative analysis of detoxification enzymes in Acrythrosiphon pisum and Myzus persicae. Insect Molecular Biology 19:155164.

Semtner, P.J., W.M. Tilson, and S.K. Dara. 1998. Performance of the tobacco aphid (Homoptera: Aphididae) on various host plants. Journal of Entomological Science 33:180-195.

Sloane, M.A., P. Sunnucks, A.C.C. Wilson, and D.F. Hales. 2001. Microsatellite isolation, linkage group identification and determination of recombination frequency in the peach-potato aphid, Myzus persicae (Sulzer) (Hemiptera: Aphididae). Genetic Research 77:251-260.

Sokal, R.R., and F.J. Rohlf. 1995. Biometry: the principles and practice of statistics in biological research. $887 \mathrm{p}$. W.H. Freeman, New York, USA.

Sunnucks, P., and D.F. Hales. 1996. Numerous transposed sequences of mitochondrial cytochrome oxidase I-II in aphids of the genus Sitobion (Hemiptera: Aphididae). Molecular Biology and Evolution 13:510-524.

Terradot, L., J.-C. Simon, N. Leterme, E. Burdin, A.C.C. Wilson, J.-P. Gauthier, and Y. Robert. 1999. Molecular characterization of clones of the Myzus persicae complex (Hemiptera: Aphididae) differing in their ability to transmit the Potato leafroll luteovirus (PLRV). Bulletin of Entomological Research 89:355363.

Thurston, R., W.T. Smith, and B.P. Cooper. 1966. Alkaloid secretion by trichomes of Nicotiana species and resistance to aphids. Entomologia Experimentalis et Applicata 9:428-432.

Wilson, A.C.C., P. Sunnucks, R.L. Blackman, and D.F. Hales. 2002. Microsatellite variation in cyclically parthenogenetic populations of Myzus persicae in Southeastern Australia. Heredity 88:258-266.

Wyatt, I.J., and P.F. White. 1977. Simple estimation of intrinsic increase rates for aphids and tetranychid mites. Journal of Applied Ecology 14:757-766. 
Xia, Y.L., and A.W. Johnson. 1997. Effects of leaf surface moisture and relative humidity on the efficacy of sugar esters from Nicotiana gossei against the tobacco aphid (Homoptera: Aphididae). Journal of Economic Entomology 90:1010-1014.

Xia, Y.L., A.W. Johnson, and O.T. Chortyk. 1997. Enhanced toxicity of sugar esters to the tobacco aphid (Homoptera: Aphididae) using humectants. Journal of Economic Entomology 90:1015-1021.
Zepeda-Paulo F.A., J.-C. Simon, C.C. Ramírez, E. Fuentes-Contreras, J.T. Margaritopoulos, A.C.C. Wilson, et al. 2010. The invasion route for an insect pest species: The tobacco aphid in the New World. Molecular Ecology (In press).

Zhu, Y.C., A.K. Dowdy, and J.E. Baker. 1999. Differential mRNA expression levels and gene sequences of a putative carboxylesterase-like enzyme from two strains of the parasitoid Anisopteromalus calandrae (Hymenoptera: Pteromalidae). Insect Biochemistry and Molecular Biology 29:417-425. 